\title{
Relatively Conscious: The Enduring Rage of Baldwin and the Education of a White Southern Baptist Queer
}

\author{
Jon-Marc McDonald SUNY Empire State College
}

\begin{abstract}
Delivered in Paris at the 2016 International James Baldwin Conference just two weeks before the killing of 49 individuals at a LGBT nightclub in Orlando, Florida on 26 June 2016, "Relatively Conscious" explores, through the eyes of an LGBT American and the words of James Baldwin, how separate and unequal life remains for so many within the United States. Written in the tradition of memoir, it recounts how, just as Paris saved Baldwin from himself, the writer's life was transformed upon the discovery of Baldwin.
\end{abstract}

Keywords: James Baldwin, LGBT, gay, religion, Christianity, Southern Baptist Convention

"Whose little boy are you?" My heart replied at once, "Why yours."

James Baldwin ${ }^{1}$

Smoke still billowed from the smoldering heap of steel and flesh of New York City's twin towers. In the throes of the calamity and heartache my new home was experiencing in September of 2001, I returned to my hometown to visit family because it seemed at least to make sense. We sat in my grandfather's blue Mercury Grand Marquis, on Hulen Street in Fort Worth, Texas, below the 820 overpass, waiting for the light to change. It was a desultory afternoon, no purpose to our drive beyond a grandfather and grandson spending time together. Then seemingly out of nowhere, my grandfather said to me, "Son, I always thought you'd be my preacher boy."

That one statement divided my life in two and set me against myself. There was the part of me that my grandfather thought worthy, the qualities that situated me firmly as his heir apparent. And there was the other part of me that damned every

James Baldwin Review, Volume 2, 2016 ( ) The Authors. Published by Manchester University Press and The University of Manchester Library 
aspiration my grandfather had for me. The breadth of the chasm this created could never be narrowed.

The air seemed heavy that September morning, and his words, long after he said them, lingered, suspended between what might have been and what actually was. It was at once the most beautiful and the most devastating thing anyone has ever said to me. One of the greatest men I have ever known, a man for whom my admiration was boundless, thought so highly of me, he thought me fit to carry on his legacy.

However, the echo of what wasn't said rang loudest that morning. The truth of my identity precluded me from the possibility of a future that would manifest any sort of dreams he might have had for me. At the age of twenty-one, I had been pushed out of the closet in a very public way. In a story as unlikely as it was true, newspaper headlines announced the secret of my sexual orientation that I had tried up until then to conceal. Most of my family found out I was gay from news accounts in which my sexual orientation was disclosed while I had been managing a United States congressional campaign. And three years later, that September afternoon in my grandfather's car, a rage crystallized that had been simmering for many years. A rage grounded in the fact that my truth, contrary to what the Good Book said, was doing everything but setting me free.

$$
\star * *
$$

They are, in effect, still trapped in a history which they do not understand; and until they understand it, they cannot be released from it.

James Baldwin ${ }^{2}$

My grandfather was a very respected leader in what is known as the Southern Baptist Convention, a peculiarly American strain of Christianity founded exclusively over the issue of slavery. As inconvenient as it might be to their present, their past begins in the year 1845, when, in an effort to preserve the economic caste system fueled by the terror of slavery, the Southern Baptists came into existence, and God-as God often is-was appropriated for their cause and used to justify the mass captivity, torture, and genocide of an entire people. ${ }^{3}$ The Southern Baptist denomination, the largest Protestant denomination of Christianity in the United States today, far from being rooted in the love, compassion, and grace of the Lord, was rooted in a greed so absolute, its brutality knew no restraint. Indeed, the poison that created the denomination continues to contaminate its worldview, and that worldview, though no longer officially pro-slavery, has found its modern-day bête noire in another unwanted, another other-namely the gay community.

Please try to remember that what they believe, as well as what they do and cause you to endure does not testify to your inferiority but to their inhumanity. 
On 28 June 2015, two days after the Supreme Court of the United States ruled in favor of so-called gay marriage, the pastor of the church in which I grew up-where my grandfather pastored for over twenty-five years, where I as a child dreamed of pastoring, where many in my family, including my mother and grandmother and aunt and cousins, still belong-that pastor preached a sermon melodramatically titled "Homeland Security." In it, he said,

"On the wicked He will rain fiery coals and burning sulfur; a scorching wind will be their lot." The raining of fiery coals, burning sulfur and scorching wind paints a picture of a volcanic eruption of God's wrath against evil. Remember how God dealt with Sodom and Gomorrah in Genesis? God will have the final word one day ... At times like this we need to understand that what God is doing, He is dealing with his church, He's dealing with us. He's purifying and He is perfecting us. We are going to see who the true believers are when the pressure becomes so intense to cave in to political pressure. ${ }^{5}$

The pastor went on to say that the very foundations of the world were being destroyed by the Supreme Court ruling and that, instead of expanding freedom for a persecuted minority, Christians were now the ones being persecuted by the ruling.

Finally, just on the cusp of tears as affected as the vibrato in his voice, with the hyperbolic richness worthy of any politician, the pastor concluded his sermon with an altar call that begged the congregants, if their "hearts were broken" over the ruling, to make their way to the altar and "fill the altar with broken hearts this morning . . . let's just cry out to God for our nation."6

He was asking my mother and my grandmother and my aunt and my cousins, and all the other mothers and grandmothers and families, to choose between their loved ones and a theology so twisted that it portends that my love is so toxic, it will destroy the foundations of my country.

I didn't know him, but he knew me. He knew Harlem, he knew poetry, he knew Jesus, and he knew my mother. He knew sin. I did not know him, but when I first read him, he knew me.

Carl Hancock Rux ${ }^{7}$

In January of 2015, I found myself in a classroom on the west side of Manhattan. Dreams of being a preacher long since abandoned, the inner conflict, the continued slights, the rage at being made the "other" coursed through every fiber of my existence. My professor was in the middle of a three-week-long lecture series about great African-American writers who, at one time or another, called New York City home. Ralph Ellison, Richard Wright, W. E. B. Du Bois, Langston Hughes, Zora Neale Hurston-all names with which I had a passing familiarity-were discussed with enthusiasm. The professor instructed us by next class to read the excerpt from The Fire Next Time by James Baldwin as listed in the syllabus. 
On the A train home that night I read part of the assignment. In a matter of a few moments, the hook was set. Just as Paris saved Baldwin from himself, nearly thirty years after his death Baldwin was about to save me from myself. Little did I know then, it was the A train that Rufus Scott took to the George Washington Bridge, located in my neighborhood. Presumably, it was the A train that Baldwin's beloved Eugene Worth rode to his suicide as well, and it was probably the A train that Baldwin rode, at least part of the time, to and from his place of birth in Harlem to the West Village.

At the time, though, I didn't know the train's significance. All I knew then was that he was writing to me, he was talking to me, he understood me in a way I scarcely understood myself. My eyes filled with tears of relief, the kind of unruly tears that fall when, deep inside, the dam breaks that you never knew you had built in the first place. In all my life, in all my pain and heartache, I never knew someone I never knew could know me so well.

And what I know is what I felt-what I feel-reading Baldwin. I know sometimes I am short of breath, that I finish a certain passage or even paragraph and I'm depleted and spent. I know that, despite my academic desire to critically analyze his words, I am usually overcome by such a visceral reaction, all other reactions are inconsequential. Like his mentor and great friend, Beauford Delaney, teaching Baldwin to see things from a different perspective by telling him to look again at a puddle of water, each turn of the page was-is-like seeing familiar places anew, refracted in innumerable directions. He leaves me with more questions than I ever thought I had, with an awareness of unknowns that I didn't know were unknown, further disruptions of concepts that I had previously thought settled.

As I continued my discovery, I uncovered what informed him. I knew the pain that Eugene experienced, the pain Baldwin experienced at losing Eugene, the pain that created Rufus, and the pain that destroyed him. As I read more, both my consciousness expanded and the world around me expanded. Baldwin knew me, he knew my rage, he knew, like a great prophet, that his words, long after he was gone, would light the way to something bigger.

I don't pretend to know Baldwin's pain. But he knew mine. He suffered more slights and aggressions in one week than I could possibly know in a lifetime. But that rage-the essence of its power and the potential of its destruction-that I know. Baldwin turned to writing and fled to Paris to save himself. I turned to Baldwin to save myself.

It turned out that the question of who I was not solved because I had removed myself from the social forces which menaced me-anyway, these forces had become interior, and I had dragged them across the ocean with me. The question of who I was had at last become a personal question, and the answer was to be found in me.

James Baldwin ${ }^{8}$ 
At the age of thirteen I, already cloistered in the protective arms of the Church, was realizing that the stirrings deep within, feelings I knew I should not know, could no longer be ignored. I also knew that, should my wretched unknown become known, the protective arms of the Church would no longer protect me. At that realization, I was filled with unfathomable fear. I did not know how I would shoulder the unbearable weight of my secret but I did know that it would be a secret I kept unto my death.

Each night, as my awakening took hold, I would plead with God to remove, as Saint Paul wrote, the thorn in my flesh. For years my prayer remained the same, promising anything if, in return, God would remove my burden.

Tormented by who I was, and unable to reconcile who I was with what I had been brought up to be, I endured a twenty-year relationship with alcohol that ended in a Manhattan hospital room, hooked up to every conceivable machine, fighting for my life, a life I wasn't quite sure I wanted to live anymore. By the time I discovered Baldwin in that Manhattan classroom I had been sober for two years. However, the pain that alcohol had anesthetized remained within, and the reality of my country continued without.

And my country's present reality is that, in 2015, more transgendered people were murdered in the United States than in any other year on record, ${ }^{9}$ that Lesbian Gay Bisexual Transgender (LGBT) youth are still committing suicide at alarming rates, that mothers and fathers are still kicking their LGBT children out of their homes, that men and women are still huddled in the closet lest their secret bring ridicule or scorn or worse. My country's present reality is that three contenders for the Republican nomination for the presidency of the United States attended and participated in a conference hosted by Kevin Swanson, a extremist American pastor who has repeatedly called for the execution of gay people. ${ }^{10}$

Despite the fact that I can now marry the person I love, the present reality in my country is that, at the time of this writing, there are still 28 states where it is perfectly legal to fire me because I married the person I love, and in those same states I can be denied housing for the same reason. ${ }^{11}$ The present reality is that, in my country, 40 percent of homeless youth are gay and 70 percent of those are on the streets because of family rejection. ${ }^{12}$

My country's present reality is witnessing the manufactured panic besieging state capital after state capital, as they respond to the Supreme Court legalizing gay marriage, wherein over one hundred pieces of legislation have been proposed to ostensibly protect "religious liberty," but in reality do nothing more than codify the right to discriminate against LGBT people. ${ }^{13}$

The notion that my country is the land of the free and the home of the brave is incongruous with our present reality; anyone relatively conscious enough to realize this must also acknowledge their rage, their approval, or perhaps worst of all, their indifference. A country's history, much like that of the Southern Baptists, that is rooted firmly and undeniably in oppression, whose entire rise, far from being brought about by the hand of Providence, was on the backs of shackled men, women, and children; a country that has used Christianity as both its sword 
and its shield, and devised such knotty justifications to keep but a select few in their place, is a country drowning in such delusion and fear that, until it is facedsquarely, brutally, without cover-it cannot ever really come to terms with where it is because it doesn't know from where it came. It can never truly come to terms with the gay problem because it has yet to come to terms with, as Baldwin put it, the negro problem.

Though I cannot claim a kinship to Baldwin's struggle as a black man, I can claim his rage. I can honor that place from where it came and I can harness that rage - my rage - so that it will not destroy me but instead will destroy the myth.

Until we look at our bloody past with unflinching clarity, we will never be free of the lies we have told ourselves in the present. In order to maintain a certain lockstep with the story many in my country continue to tell, they must willfully ignore the unseemly parts, the parts that would force them to face their own humanity and lack thereof. We live in a time where leaders in my country actively seek to end the rights of two men committed to love, yet do nothing to abridge the ease with which two men committed to murder can buy assault rifles; when those same leaders feign worry for children about whether the wrong gender might use the "wrong" bathroom, yet do nothing to help lift 16 million children in their country out of the throes of poverty. We are adrift in a cultural schizophrenia so far removed from reality that we needn't worry about the foundations crumbling, because the foundations were never there to begin with.

When I consider all that Baldwin has meant to me in the brief time since discovering him, all the tangled thoughts he has untangled, all the inexpressible ideas that he was able to express, when I reflect on how his words become life every time I read and re-read them, each time I watch an interview or hear an anecdote or visit a place where he once dined or lived or fled, I am struck not by the impossibility of Baldwin as an esoteric pursuit but instead by how well a Pentecostal black man from Harlem, born in the early twentieth century, could know me, a gay white man from the Deep South born in the latter part of the same century.

When Baldwin writes of white people choosing willful ignorance so that they need never face the harsh realities of their sustained crimes against blacks, when he writes of a world that is set up so that his nephew and others like him should live by the ghetto and die by the ghetto, when he writes that white people do not want to know the price that black people had to pay; indeed when he writes of the concepts of 'white' and 'black' being nothing but political constructs, I can't help but draw the parallel. I can't help but find that the world into which many of my LGBT sisters and brothers were born was set up so that they remain fixed in the firmament of the second class, to remain voiceless in the closet, to never speak up or speak out or demand anything beyond simple tolerance. 
We are very cruelly trapped between what we would like to be and what we actually are. And we cannot possibly become what we would like to be until we are willing to ask ourselves just why the lives we lead on this continent are mainly so empty, so tame, and so ugly.

James Baldwin ${ }^{14}$

Who can blame them, these "innocents" as Baldwin calls them? ${ }^{15}$ Who can blame them for never facing the depth of their depraved history? It would require that the entirety of what they believe God to be, be unveiled as nothing but a lie. If the notion of God and of his so-called truths is predicated on infallibility, then if one of those truths is admitted to be false, the entire structure collapses.

This, of course, is irrelevant. Just as Baldwin declared about race, none of LGBT discrimination is about God's eternal truth. It is about protecting the myth to further their superiority. They need me to be gay so that they can be straight, to be a them to their us, to be the damned to their eternal life. The myth is that they are saved, the myth is that they are the purveyors of truth, and the only way their myth works - the only way-is for it to be believed. It is the great lie Baldwin exposed, and it is a lie that permeates to this day. It requires its labels be adhered to and its players play their roles.

The day will come when you will trust you more than you do now, and you will trust me more than you do now. And we can trust each other. I do believe, I really do believe in the New Jerusalem, I really do believe that we can all become better than we are. I know we can. But the price is enormous-and people are not yet willing to pay it.

James Baldwin ${ }^{16}$

I didn't know Baldwin but he knew me. And he implores us today, in the midst of a world on fire, suffering the pangs of its dissonance, its greed, indeed its denial, to pursue still that New Jerusalem. Yet, when his country and mine is incarcerating people at astonishing rates, when young children are shot dead in the streets by police with impunity, when presidential candidates are calling for violence against dissenters, when some are calling for the denial of entry to the shores of my land to certain people for nothing more than the God that they proclaim, a New Jerusalem seems naïve. And yet he has called us, each, collectively, from all corners of the globe, all pockets of civilization, to resist the cynicism that suggests that a new way forward is a distant memory.

If the concept of God has any validity or any use, it can only be to make us larger, freer, and more loving. If God cannot do this, then it is time we got rid of Him.

James Baldwin ${ }^{17}$ 
If Baldwin has taught us anything it is that we are to hold fast to his rage, to our rage, only as much as it can drive us toward forgiveness, reconciliation, change, love, and ever closer to the New Jerusalem. If rage can't do that, like God, it must be discarded.

He taught us that our sins must not only be viewed through history's long lens, but instead must also be scrutinized through the magnifying mirror of the present, that we must wake from our self-induced slumber and face our inscrutable reality and make sense of it at last. He demands that we not be idealistic but that we not succumb to cynicism, either.

The very time I thought I was lost,

My dungeon shook and my chains fell off. ${ }^{18}$

Just as he wrote to his nephew, we are not free until they are free, and their freedom is directionally proportional to our truth. We are all Baldwin's nephews now, and, as such, we are to be a beacon of reality, a force that shows things as they are rather than as we would wish them to be, steadfast in the hope of things as they could be rather than as they are.

These are the impossible things, and the cynics have deemed us the dreamers who chase the dreams unattainable. The tongue clickers are clicking their tongues and the prognosticators are prognosticating that the world is beyond our reach, that reality is too much to bear for too many and that we are, individually, inches from our collective destruction.

But I do believe, and I do believe that if Baldwin were here he would believe it too. Though the world is burning and though the price is high, if we can manage, as he wrote, to face in ourselves what we face in others, with wisdom and compassion, hope for our civilization can be found.

I believe that the dungeons are shaking, still

I believe the chains are falling, still

I believe that the New Jerusalem is possible.

Still.

\section{Notes}

1 James Baldwin, The Fire Next Time (1963) (New York, Vintage, 1993), p. 29.

2 Ibid., p. 8.

3 Jennifer Ludden, "Southern Baptists Apologize For Slavery Stance," 28 August 2008, National Public Radio, http://www.npr.org/templates/story/story.php?story $\mathrm{Id}=112329862$ (accessed 28 June 2016).

4 Baldwin, The Fire Next Time, p. 8.

5 Michael Dean, "Homeland Security," 28 June 2015, https://www.youtube.com/ watch?v=Hbm9zMxI0fU (accessed 12 May 2016). This quote begins with a direct recitation of Psalm 11:6, though Dean doesn't explicitly cite the verse.

6 Ibid. 
7 Carl Hancock Rux, “On The Avenue," para. 3, PEN America, n.d., https://pen.org/non fictiontranscript/james-baldwins-grand-tour (accessed 12 May 2016).

8 James Baldwin, "Introduction" (1961), in Nobody Knows My Name (New York, Vintage 1993).

9 Khorri Atkinson, "More Transgender People Reported Killed in 2015 than in Any Other Year," MSNBC, 20 November 2015, http://www.msnbc.com/msnbc/more-transgenderpeople-reported-killed-2015-any-other-year (accessed 28 June 2016).

10 BrianTashman, "Cruz,HuckabeeandJindalWillJoin PastorWhoWantsGays PuttoDeath," Right Wing Watch, 9 October 2015, http://www.rightwingwatch.org/content/cruzhuckabee-and-jindal-will-join-pastor-who-wants-gays-put-death (accessed 28 June 2016).

11 Emma Green, "Can States Protect LGBT Rights Without Compromising Religious Freedom?" The Atlantic, 5 January 2016, http://www.theatlantic.com/politics/archive/ 2016/01/lgbt-discrimination-protection-states-religion/422730/(accessed28June2016); "Equality Maps: Non-Discrimination Laws," Movement Advancement Project, 30 June 2016, http://www.lgbtmap.org/equality-maps/non_discrimination_laws (accessed 6 July 2016). The 28 states that lack non-discrimination laws for LGBT populations in both housing and private sector employment are Alabama, Alaska, Arizona, Arkansas, Florida, Georgia, Idaho, Indiana, Kansas, Kentucky, Louisiana, Michigan, Mississippi, Missouri, Montana, Nebraska, North Carolina, North Dakota, Ohio, Oklahoma, Pensylvania, South Carolina, South Dakota, Tennessee, Texas, Virginia, West Virginia, Wyoming.

12 L. E. Durso and G. J. Gates, "Serving Our Youth: Findings from a National Survey of Service Providers Working with Lesbian, Gay, Bisexual, and Transgender Youth who are Homeless or At Risk of Becoming Homeless" (Los Angeles, The Williams Institute, 2012).

13 Jennifer Bendery and Michael Signorile, "Everything You Need to Know About the Wave of 100+ Anti-LGBT Bills Pending In States," The Huffington Post, 15 April 2016, http://www.huffingtonpost.com/entry/lgbt-state-bills-discrimination_us_570ff4f2e4b0060ccda2a7a9 (accessed 28 June, 2016).

14 James Baldwin, "Mass Culture and the Creative Artist: Some Personal Notes" (1959), in The Cross of Redemption: Uncollected Writings, ed. Randall Kenan (New York, Pantheon, 2010), p. 6 .

15 Baldwin, The Fire Next Time, p.9.

16 Prod. Karen Thorsen and William Miles, dir. Karen Thorsen, James Baldwin: The Price of the Ticket, California Newsreel, 1989.

17 Baldwin, The Fire Next Time, p. 47.

18 Ibid., p. 9.

\section{Works Cited}

Atkinson, Korri, "More Transgender People Reported Killed in 2015 than in Any Other Year," MSNBC, 20 November, 2015, http://www.msnbc.com/msnbc/more-transgenderpeople-reported-killed-2015-any-other-year (accessed 28 June 2016).

Baldwin, James, The Fire Next Time (1963) (New York, Vintage, 1993).

"Introduction" (1961), in Nobody Knows My Name (New York, Vintage, 1993).

"Mass Culture and the Creative Artist: Some Personal Notes" (1959), in The Cross 
of Redemption: Uncollected Writings, ed. Randall Kenan (New York, Pantheon, 2010), pp. 1-6.

Bendery, Jennifer, and Michael Signorile, "Everything You Need to Know About the Wave of 100+ Anti-LGBT Bills Pending in States," The Huffington Post, 15 April 2016, http:// www.huffingtonpost.com/entry/lgbt-state-bills-discrimination_us_570ff4f2e4b0060ccda2a7a9 (accessed 28 June 2016).

Dean, Michael, "Homeland Security," 28 June 2015, https://www.youtube.com/watch?v=Hbm9zMxI0fU (accessed 12 May 2016).

Durso, L. E., and G. J. Gates, "Serving Our Youth: Findings from a National Survey of Service Providers Working with Lesbian, Gay, Bisexual, and Transgender Youth who are Homeless or At Risk of Becoming Homeless" (Los Angeles, The Williams Institute, 2012).

N.A. "Equality Maps: Non-Discrimination Laws," Movement Advancement Project, 30 June 2016, http://www.lgbtmap.org/equality-maps/non_discrimination_laws (accessed 6 July 2016).

Green,Emma, "Can States ProtectLGBT Rights WithoutCompromising Religious Freedom?" The Atlantic, 5 January 2016, http://www.theatlantic.com/politics/archive/2016/01/lgbtdiscrimination-protection-states-religion/422730/ (accessed 28 June 2016).

Ludden, Jennifer, "Southern Baptists Apologize For Slavery Stance," 28 August 2008, NationalPublicRadio,http://www.npr.org/templates/story/story.php?storyId=112329862 (accessed 28 June 2016).

Rux, Carl Hancock, "On The Avenue," PEN America, n.d., https://pen.org/nonfictiontranscript/james-baldwins-grand-tour (accessed 12 May 2016).

Tashman, Brian, "Cruz, Huckabee and Jindal Will Join Pastor Who Wants Gays Put to Death," Right Wing Watch, 29 October 2015, http://www.rightwingwatch.org/content/ cruz-huckabee-and-jindal-will-join-pastor-who-wants-gays-put-death (accessed 28 June 2016).

Thorsen, Karen (dir.), James Baldwin: The Price of the Ticket (California Newsreel, 1989).

\section{Contributor's Biography}

Jon-Marc McDonald is pursuing a degree in creative writing at SUNY Empire State College in New York City where he serves as editor-at-large for the Metropolitan Review, the college's literary and arts journal of student expression. In addition to his studies, McDonald is a publicist for individuals within the entertainment industry. 